This paper was prepared during the tenure by R. M. A. of a Commonwealth Fund Senior Travelling Fellowship at the London School of Hygiene and Tropical Medicine with Professor J. N. Morris. I am indebted to Dr. J. S. Lawrence, of the Arthritis and Rheumatism Council, for data from his population surveys.

\section{REFERENCES}

Acheson, R. M. (1968). In Population Studies of the Rheumatic Diseases, edited by P. H. Bennett and P. H. N. Wood, p. 490. Amsterdam, Excerpta Medica Foundation

Acheson, R. M. (1969). Procesdings of the Royal Society of Medicine. In press.

Acheson, R. M., and Chan, Y.-K. (1969). Fournal of Chronic Diseases, 21, 543.

Acheson, R. M., and Florey, C. du V. (1969). Lancet, 2, 391.

Achesun. R. M., and O'Brien, W. M. (1966). Lancet, 2, 777.

Acheson, R. M., and O'Brien, W. M. (1968). In Population Studies of the Rheumatic Diseases, edited by P. Bennett and P. Wood, p. 365. Amsterdam, Excerpta Medica Foundation.

Ansell, B. M., and Lawrence, J. S. (1966). Annals of the Rheumatic Diseases, $25,67$.

Bremner, J. M. (1961). Annals of the Rheumatic Diseases, 20, 149

Broaks, G. W., and Mueller, E. (1965). fournal of the American Medical Association, 195, 415.

Cobb, S (1963). In The Epidemiology of Chronic Rheumatism, edited by J. Kellgren, M. Jeffrey, and J. Ball, p. 182. Oxford, Blackwell Scientific Publications.
Cobb, S., Dunn, J. P., Brooks, G., and Rodnan, G. P. (1961). Arthritis and Rheumatism, 4, 412.

Dunn, J. P., Brooks, G. W., Mausner, J., Rodnan, G. P., and Cobb, S. (1963).' Journal of the American Medical Association, 185, 431.

General Register Office (1950). Classification of Occupations. London, H.M.S.O.

Gordon, M. (1963). Social Class in American Sociology, New York, McGraw-Hill.

Follingshead, A. B. (1957). Two Factor Index of Social Position. Unpublished.

Kasl, S. V., Brooks, G. W., and Cobb, S. (1966). Fournal of the American Medical Association, 198, 713.

Kellgren, J. H. (1964). Annals of the Rheumatic Diseases, 23, 109.

Liddle, L., Seegmiller, J. E., and Laster, L. (1959). Fournal of Laboratory and Clinical Medicine, 54, 903.

McCarty, D. J. (1964). Arthritis and Rheumatism, 7, 726.

Montoye, H. J., Faulkner, J. A., Dodge, H. J., Mikkelsen, W. M., Willis, P. W., and Block, W. D. (1967). Annals of Internal Medicine, 66, 838.

Oser, B. L. (editor) (1965). In Hawk's Physiological Chemistry, 14th ed., p. 1046. New York, McGraw-Hill.

O'Sullivan, J. B., Francis, J., and Kantor, N. (1965). Clinical Chemistry, $11,427$.

Popert, A. J., and Hewitt, J. V. (1962). Annals of the Rheumatic Diseases, $21,154$.

Rodnan, G. P. (1961). Arthritis and Rheumatism, 4, 27.

Weber, M. (1953). In Class, Status and Power, edited by R. Bendix and S. Martin, p. 64. New York, Free Press of Glencoe.

\title{
White Blood Count in Patients on Regular Haemodialysis
}

\author{
M. PAPADIMITRIOU,* M.D.; L. R. I. BAKER, $†$ M.B., M.R.C.P.; B. SEITANIDIS, $\ddagger$ M.D. \\ L. H. SEVITT,§ M.B., M.R.C.P. ; A. E. KULATILAKE,\| F.R.C.S., F.R.C.S.ED.
}

\begin{abstract}
Summary : Total white cell, neutrophil, and lymphocyte counts were compared in patients with chronic renal failure treated successively by conservative means (lowprotein diet), regular haemodialysis, and renal allotransplantation. The lowest total white cell and neutrophil counts and the highest lymphocyte counts were found in patients on regular haemodialysis. A rapid fall in neutrophil count during the first half-hour of dialysis and a more gradual fall between the first and sixth hours were observed. Adherence of neutrophils and mononuclear cells to the cuprophane (PT 150) dialysis membrane has been shown.
\end{abstract}

\section{Introduction}

The total white cell count has been reported to be high in cases of acute renal failure and high or normal in cases of chronic renal failure; neutrophil leucocytosis and lymphopenia is common to both (Jensson, 1958 ; Riis and Stougaard, 1959). The cause of lymphopenia in uraemia is obscure, as is also neutrophil leucocytosis in the absence of infection. It may be that substances retained in the body because of renal failure depress lymphopoiesis and stimulate granulopoiesis, though the identity of such substances is unknown. Little is known of the behaviour of the white cells in patients on regular haemodialysis, where uraemia is well controlled, though infections are common in such patients.

This paper is a retrospective study of the white blood count in patients with chronic renal failure during three periods:

\footnotetext{
* Honorary Registrar and N.A.T.O. Scholar, Department of Surgery.

+ Registrar and Tutor in Medicine.

¥ Registrar in Haematology.

Fenior Registrar, Department of Medicine.

|| Senior Registrar and Tutor in Surgery.

Hammersmith Hospital and Royal Postgraduate Medical School, London $\mathbf{W} .12$.
}

on conservative treatment (low-protein diet), on regular haemodialysis, and during the early stage after renal allotransplantation. In addition the acute effect of haemodialysis on the white blood count has been examined.

\section{Material and Methods}

Twenty patients ( 10 male and 10 female) were studied. Their mean age was 32 years, with a range from 18 to 46 . The underlying disease was chronic pyelonephritis in 10 , chronic glomerulonephritis in five, two were anephric (bilateral nephrectomy), one had polycystic kidneys, one familial nephritis, and one a solitary hydronephrotic kidney. The total white blood count and the differential, were studied in three periods: on restricted protein diet (13 patients), on haemodialysis (all 20 patients), and during the early stage (first four months) after renal transplantation (12 patients).

The first and third periods of study extended over at least four months, seven and eight patients respectively being excluded because this criterion was not fulfilled. Patients on haemodialysis were studied for at least six months. During the first period the patients were on a modified GiordanoGiovannetti diet, usually containing about $20 \mathrm{~g}$. of protein. During the second period they were dialysed overnight (beginning dialysis at about 6 to 8 p.m. and ending 12 hours later) twice-weekly by means of Kiil dialysers with Lucas monitors and a single-pass automatic dialysate supply. The membranes used were cuprophane PT 150. Heparin was given during dialysis in a priming dose of 10,000 international units (i.u.) followed by 5,000 i.u. every three hours. Whole-blood clottingtime during dialysis was maintained over 20 minutes. During the last hour of dialysis the dialyser was tipped vertically in order to reduce the retention of blood between the membranes.

All patients on dialysis were on a diet containing $0.7-0.9 \mathrm{~g}$. of protein per kg. body weight and were taking folic acid 
$5 \mathrm{mg}$. t.d.s. and Multivite three tablets daily. Nine of the 12 transplanted patients received a cadaveric kidney and three received kidneys from live related donors. The postoperative immunosuppressive therapy consisted of prednisome $(300 \mathrm{mg}$. daily for the first three days, reducing by half every three days until the maintenance dose of $15 \mathrm{mg}$. daily was reached) and azathioprine $0 \cdot 2-0.4 \mathrm{mg} . / \mathrm{kg}$. body weight, depending on the urine volume and on the presence or absence of infection. Rejection was treated as described elsewhere (Chisholm et al., 1969). The white blood counts during episodes of infection and after minor operations such as insertion or removal of the Teflon-Silastic arteriovenous shunt were not excluded from the study.

In the first and third periods blood samples were taken by venepuncture. In the second period blood samples were obtained from the arterial side of the Teflon-Silastic arteriovenous shunt just before dialysis was begun. Arterial and venous total and differential white cell counts do not differ significantly (Kaplow and Goffinet, 1968). The total white blood count was measured by a Coulter automatic cell counter (model A). Neutrophil and lymphocyte counts were calculated indirectly, the differential white blood count deduced from smears stained by May-Grunwald-Giemsa being used. The means of the above counts for each patient were found and used for the statistical analysis.

The acute effect of haemodialysis on leucocytes was investigated as follows: in 17 patients (14 of whom did not correspond to the patients already studied) total and differential white counts were measured immediately before and after completion of dialysis on a total of 23 occasions, the blood sample again being obtained from the arterial side of the arteriovenous shunt. From 11 patients arterial samples for total and differential white cell coumts were obtained before a subsequent dialysis and $\frac{1}{2}, 1,3,6,9$, and 12 hours after its commencement. In four patients changes in white cell count occurring during the first 30 minutes of dialysis were studied, arterial blood samples being obtained immediately before and at 5, 10, 20, and 30 minutes after starting dialysis.

Finally, pieces of cuprophane, used for a single haemodialysis and washed repeatedly with normal saline, were stained with haematoxylin eosin to show the presence of white blood cells on the membrane.

\section{Results}

The mean ( \pm S.D.) of the total white cell, neutrophil, and lymphocyte counts in the peripheral blood and the significance of the differences observed ( $t$ test for unpaired data) during the three periods of study are shown in Fig. 1. Patients on

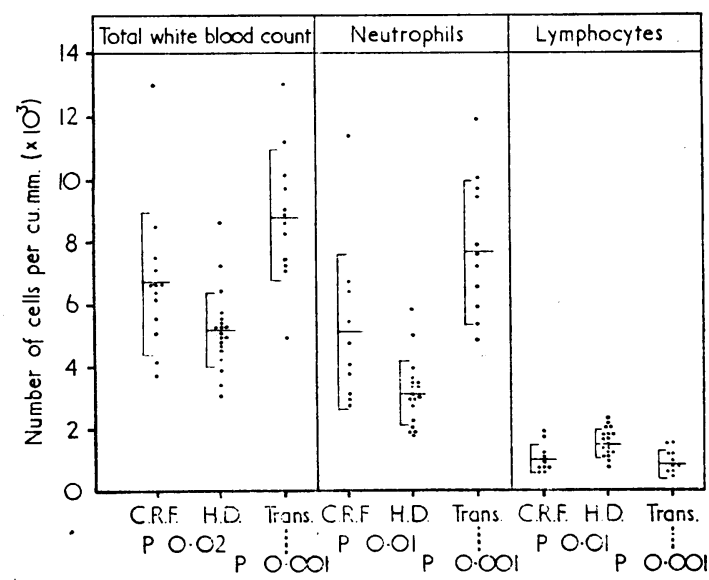

FIG. 1.-Means ( \pm S.D.) and stat.stical differences of the total white cell, neutrophil, and lymphocyte counts in patients on low-protein dict (C.R.F.), regular haemodialysis (H.D.), and during the early stage after renal allotransplantation (Trans) ( $t$ test for unpaired data). haemodialysis showed a significant fall in the total white cell and neutrophil counts $(P<0.02$ and $P<0.01$ respectively) and a significant rise in the lymphocyte count $(P<0.01)$ compared with values obtained during period 1 . The mean difference of the neutrophil count between the first period (on diet) and the second one (on haemodialysis) was $2,000 / \mathrm{cu}$. $\mathrm{mm}$. During the early stage after transplantation there was a highly significant increase in the total white cell and neutrophil counts and a highly significant fall in the number of lymphocytes $(\mathbf{P}<0.001)$ compared with values obtained in period 2 . The mean difference in neutrophil count between the second period (haemodialysis) and the third one (transplantation) was 4,500 cells/cu. mm.

During all 23 haemodialyses studied the total white blood count fell (Fig. 2). The mean count before haemodialysis was

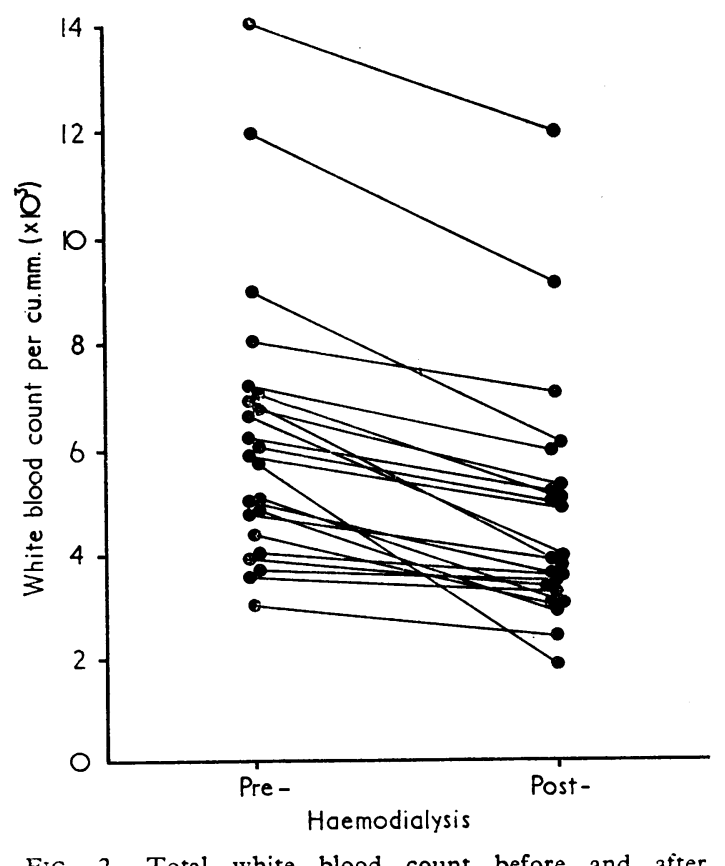

Fig. 2.-Total white blood count before and after haemodialysis.

6,300 and after $4,600 / \mathrm{cu}$. mm., though the packed cell volume (P.C.V.) in all the above instances was steady or increased (mean increase $=6.4 \%$ ). Serial measurements on 11 occasions showed that a rapid fall in total white cell and neutrophil counts occurred in the first half-hour after starting dialysis (Fig. 3). At the end of the first hour a rise in neutrophil count

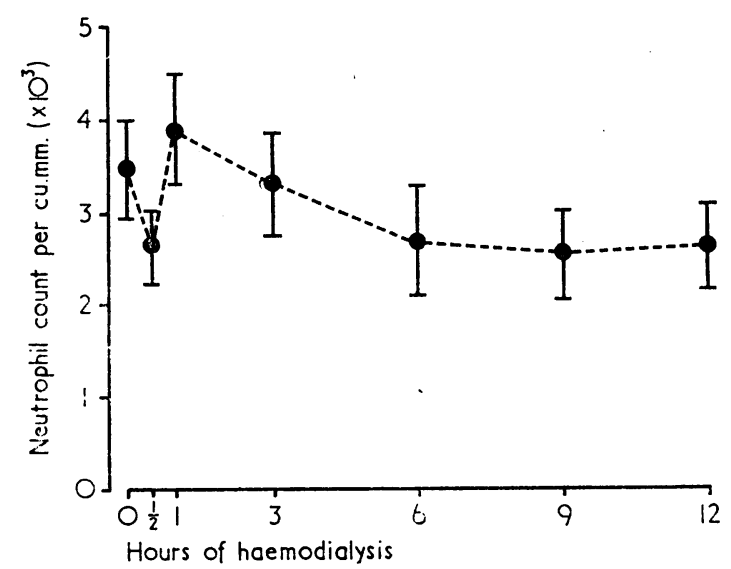

FIG. 3.-Mean neutrophil count ( \pm S.E. of mean) during dialysis of 11 patients.

was observed, and up to six hours there was a gradual fall. From six hours to the end of dialysis the neutrophil count 
remained steady. The lymphocyte count was steady throughout dialysis.

An acute fall in neutrophil count was seen during the first 30 minutes of dialysis. The maximum fall occurred 10 minutes after starting dialysis (see Table).

Neutrophil and Lymphocyte Counts per cu. mm. during First Half-hour

\begin{tabular}{|c|c|c|c|c|c|c|c|c|}
\hline & \multicolumn{2}{|c|}{ Case 1} & \multicolumn{2}{|c|}{ Case 2} & \multicolumn{2}{|c|}{ Case 3} & \multicolumn{2}{|c|}{ Case 4} \\
\hline & N. & L. & N. & L. & N. & L. & N. & L. \\
\hline $\begin{array}{l}\text { Pre-dialysis } \\
5 \text { minutes } \\
10 \% \\
20 \% \\
30 \%\end{array}$ & $\begin{array}{r}1,505 \\
1,610 \\
36 \\
364 \\
1,558\end{array}$ & $\begin{array}{l}2,193 \\
1,470 \\
1,512 \\
1,898 \\
1,968\end{array}$ & $\begin{array}{r}1,178 \\
1,184 \\
288 \\
420 \\
924\end{array}$ & $\begin{array}{l}1,406 \\
1,408 \\
1,464 \\
2,310 \\
1,260\end{array}$ & $\begin{array}{r}1,376 \\
1,332 \\
153 \\
342 \\
1,490\end{array}$ & $\begin{array}{l}2,494 \\
1,887 \\
1,547 \\
1,444 \\
1,666\end{array}$ & $\begin{array}{r}2,440 \\
528 \\
180 \\
2,090\end{array}$ & $\begin{array}{l}1,200 \\
1,752 \\
1,260 \\
1,558\end{array}$ \\
\hline
\end{tabular}

Fig. 4 shows the accumulation of white blood cells (neutrophils and mononuclear cells) on the cuprophane membrane at the end of a 12-hour haemodialysis. It will be noted that red cells have been completely removed from the membrane by the saline wash-in at the end of dialysis.

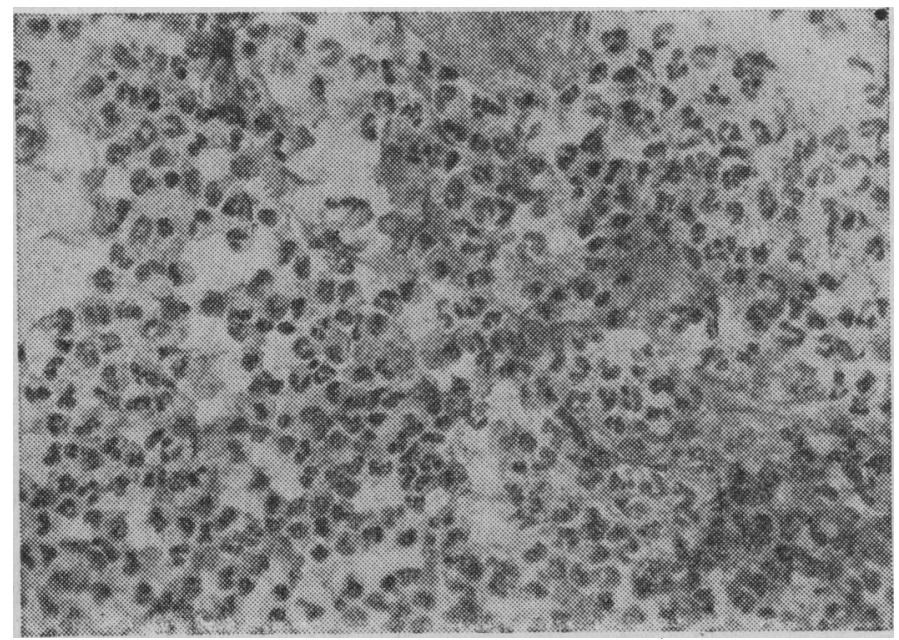

FIG. 4.-White blood cells (neutrophils and mononuclear cells) on a piece of cuprophane membrane (PT 150) at the end of a 12-hour haemodialysis. (H. and E. $\times 70$.)

\section{Discussion}

The problem of damage to the corpuscular elements of the blood is of fundamental importance in the design and operation of perfusion systems such as heart-lung machines, artificial hearts, and artificial kidneys. Indeed, it is one of the remaining obstacles to the continuous use of such devices for long periods of time (Kusserow and Kendall, 1963).

Kaplow and Goffinet (1968) reported a transient and profound neutropenia occurring 2 to 15 minutes after starting haemodialysis with a twin-coil dialyser, without any symptoms or apparent clinical sequelae. Heparin and the polyvinyl administration tubing were excluded as causes of the neutropenia and, indeed, heparin has been reported to produce leucocytosis (Filkins and Di Luzio, 1968). Falls in neutrophil count of the order found over a 12-hour dialysis might be attributed to diurnal changes in the count (Sharp, 1960), if it is assumed that the diurnal rhythm is unaffected by uraemia, though such changes are found inconstantly (Garrey and Bryan, 1935) whereas they were invariably present in our patients (Fig. 2). The acute fall in neutrophil count occurring during the first half-hour of dialysis cannot be explained in this way. It seems likely that this fall is due, at least in part, to sequestration of neutrophils within the body as suggested by Kaplow and Goffinet (1968), though adherence of neutrophils to the cuprophane membrane (Fig. 4) may also be a factor. The rapid return of neutrophil count to normal is presumably due largely to mobilization of neutrophils from the marginal pool of the blood (Wintrobe, 1967).

Whether or not repeated removal of neutrophils from the circulation contributes appreciably to the lower neutrophil counts observed in patients on haemodialysis is unknown. The ability of the marrow to increase granulopoiesis and the small size of the circulating as opposed to the total neutrophil pool suggest that this is not the only factor involved. Similarly, it is not known whether regular lcucophoresis is one of the causes of the relatively high incidence of infections in patients on regular haemodialysis (Carroll et al., 1969). Bone marrow examination showed normal granulopoiesis in our patients on regular haemodialysis, and all patients who developed infections responded with a polymorphonuclear leucocytosis.

Probably many factors were responsible for the observed changes in total white cell, neutrophil, and lymphocyte counts in patients on haemodialysis and after transplantation. The rise in lymphocyte count on haemodialysis may be largely a result of partial correction of the biochemical consequences of chronic renal failure. The influence of correction of uraemia on total white cell and neutrophil counts is difficult to assess. The rise in neutrophil count after transplantation is due, in all probability, to a combination of operation, infection, graft rejection, and steroid therapy and the-corresponding fall in lymphocyte count is likely to be a consequence of treatment with steroids and azathioprine.

We wish to thank Professur R. Shackman and Dr. O. M. Wrong for permission to study these patients, who were under their care. Thanks are also due to the technicians of the department of haematology for their help.

Requests for reprints should be addressed to A. E. Kulatilake.

\section{REFERENCES}

Carroll, R. N. P., Papadimitriou, M., and Kulatilake, A. E. (1969). Unpublished data.

Chisholm, G. D., Papadimitriou, M., Kulatilake, A. E., and Shackman, R. (1969). Lancet, 1, 904.

Filkins, J. P., and Di Luzio, N. R. (1968). American fournal of Physiology, 214, 1074.

Garrey, W. E., and Bryan, W. R. (1935). Physiological Review, 15, 597.

Jensson, O. (1958). British fournal of Haematology, 4, 422.

Kaplow, L. S., and Goffinet, J. A. (1968). Fournal of the American Medical Association, 203, 1135.

Kusserow, B. K., and Kendall, L. W. (1963). Transactions. American Society for Artificial Internal Organs, 9, 262.

Riis, P., and Stougaard, J. (1959). Danish Medical Bulletin, 6, 85.

Sharp, G. W. G. (1960). Fournal of Endocrinology, 21, 97.

Wintrobe, M. M. (1967). Clinical Hematology, 6th ed., p. 259. London, Kimpton. 